\title{
Molecular Mechanisms Involved in HCC Recurrence after Direct-Acting Antiviral Therapy
}

\author{
Rosanna Villani ${ }^{\circ}$, Gianluigi Vendemiale and Gaetano Serviddio * \\ C.U.R.E. University Centre for Liver Disease Research and Treatment, Department of Medical and Surgical \\ Sciences, Institute of Internal Medicine, University of Foggia, 71122 Foggia, Italy; rosanna.villani@unifg.it (R.V.); \\ gianluigi.vendemiale@unifg.it (G.V.) \\ * Correspondence: gaetano.serviddio@unifg.it; Tel.: +39 0881741587
}

Received: 9 October 2018; Accepted: 19 December 2018; Published: 22 December 2018

\begin{abstract}
Chronic hepatitis $C$ is associated with a high risk of developing hepatocellular carcinoma (HCC) because of a direct effect of the Hepatitis C Virus (HCV) proteins and an indirect oncogenic effect of chronic inflammation and impaired immune response. The treatment of chronic hepatitis $\mathrm{C}$ markedly reduces all-cause mortality; in fact, interferon-based treatment has shown a reduction of HCC incidence of more than $70 \%$. The recent introduction of the highly effective direct-acting antivirals (DAAs) has completely changed the scenario of chronic hepatitis $\mathrm{C}$ (CHC) with rates of $\mathrm{HCV}$ cure over $90 \%$. However, an unexpectedly high incidence of HCC recurrence was observed in patients after DAA treatment ( $27 \%$ versus $0.4-2 \%$ in patients who received interferon treatment). The mechanism that underlies the high rate of tumor relapse is currently unknown and is one of the main issues in hepatology. We reviewed the possible mechanisms involved in HCC recurrence after DAA treatment.
\end{abstract}

Keywords: direct-acting antivirals; hepatocellular carcinoma

\section{Introduction}

Chronic viral hepatitis is a well-recognized risk factor for end-stage liver disease and liver cancer [1]. Among primary liver cancers, hepatocellular carcinoma (HCC) accounts for $70 \%$ to $85 \%$ of cases [2] and it is currently the fifth most common cancer [3] and the third leading cause of cancer mortality in the world [4].

In most cases, cirrhosis promotes hepatocyte regeneration and precedes HCC occurrence $[5,6]$.

Compared with other causes of cirrhosis, chronic hepatitis $C$ is associated with a higher risk of developing HCC $[5,7]$ because the Hepatitis C Virus (HCV) owns a direct oncogenic effect; moreover, chronic inflammation, impairment of immune response, cellular senescence, and proliferation indirectly depend on HCV disease [8-10].

Direct oncogenic effects of HCV are related to the cellular expression of viral proteins localized in the cytosol, lipid droplets, endoplasmic reticulum, mitochondria, and nuclei, affecting a variety of cellular functions [10].

Overexpression of HCV proteins, e.g., core, NS3, and NS5A, promotes cellular proliferation, transformation and tumor formation in mice, suggesting a direct effect in activating oncogenic pathways [10-14]. The core protein modulates p53 regulatory activity and directly influences the p53-related p73 protein $[15,16]$ whereas NS3 and NS5A inhibit p53 $[17,18]$. NS5A promotes evasion from apoptosis by caspase-3 inhibition [19] and inhibits tumor necrosis factor-alpha (TNF $\alpha$ ) mediated apoptosis [20], whereas NS5B inhibits the retinoblastoma-associated protein (RB1), which is involved in controlling cellular proliferation and apoptosis by regulating transcription factors [21]. 
Moreover, viral proteins indirectly regulate innate immune pathways: NS3 suppresses innate immunity by cleavage of the mitochondrial antiviral signaling protein (MAVS), a pivotal antiviral protein involved in interferon induction [22]; the binding of the hepatitis $C$ virus envelope protein E2 to CD81 causes inhibition of natural killer (NK) cells contributing to immune evasion [23]; HCV core protein inhibits hepatocyte senescence, a physiological process providing a barrier to tumorigenesis [24].

HCV-induced HCC is, therefore, a model of chronic inflammation-driven tumor, where a complex interaction between viruses and hepatocytes occurs, promoting hepatocarcinogenesis [10].

The cure of HCV infection defined as the absence of circulating HCV RNA at least 12 weeks after treatment completion (sustained virologic response-SVR), is associated with a marked reduction of the all-cause mortality [25] and particularly, with a reduction of more than $70 \%$ of HCC [26]. Compared with interferon-based treatments, direct-acting antivirals (DAAs) achieve SVR rates in over $90 \%$ of patients, irrespective of fibrosis stage [27-29] and this may significantly improve the natural history of HCV infection. Therefore, DAAs are currently the most promising strategy for reducing the future burden of HCC [30,31]. However, several recent reports have raised concerns about DAA treatment because a higher incidence of HCC recurrence has been observed in patients during and after antiviral treatment [32-39]. These studies have also reported an unexpectedly high incidence of de novo HCC in addition to a particularly aggressive behavior of HCC relapse. A recurrence rate up to $27 \%$ (versus $0.4-2 \%$ in patients with SVR after interferon treatment) $[36,40]$ has sparked debate on a possible role of DAAs on hepatocellular carcinoma progression and recurrence. Nonetheless, given the lack of robust evidence of a drug-related effect, many authors have investigated all factors potentially involved in promoting liver cancer during or after antiviral treatment.

We reviewed the recent literature that might explain the HCC recurrence after DAA treatment for chronic HCV infection (Table 1 and Figure 1).

Table 1. Summary of potential mechanisms involved in HCC recurrence.

\begin{tabular}{|c|c|c|c|}
\hline Hypothesis & Molecular Mechanism & Author & Ref. \\
\hline \multirow{9}{*}{ Immune cell dysfunction } & Modulation of $\mathrm{T}$ cell activation & Meissner et al., 2014 & [41] \\
\hline & Reduced NK cell activation & Burchill et al., 2015 & [42] \\
\hline & Downregulation of NKG2A receptor & Spaan et al., 2016 & {$[43]$} \\
\hline & Declined IL12p40, IL-18 serum level & Spaan et al., 2016 & [43] \\
\hline & $\begin{array}{l}\text { Modulation of differential white } \\
\text { blood cell count }\end{array}$ & $\begin{array}{l}\text { Casadei Gardini et al., } \\
2018\end{array}$ & {$[44]$} \\
\hline & Imbalance in NK cell subgroups & Chu et al., 2017 & [45] \\
\hline & Decreased NKG2D & Chu et al., 2017 & {$[45]$} \\
\hline & Decreased frequencies of NK cells & $\begin{array}{l}\text { Ning et al., 2017; } \\
\text { Meissner et al., } 2017\end{array}$ & $\begin{array}{l}{[46]} \\
{[47]}\end{array}$ \\
\hline & Immunosuppressive Tregs function & Langhans et al., 2017 & {$[48]$} \\
\hline \multirow{4}{*}{$\begin{array}{l}\text { Change in immune } \\
\text { cytokine network }\end{array}$} & Rapid reduction of IL-10 serum level & Villani et al., 2016 & [49] \\
\hline & Increased $\mathrm{TNF} \alpha$ secretion & Debes et al., 2018 & {$[50]$} \\
\hline & Change in IL-6 serum level & Debes et al., 2018 & {$[50]$} \\
\hline & Change in IL-18 serum level & $\begin{array}{l}\text { Spaan et al., 2016; } \\
\text { Ning et al., 2017; } \\
\text { Carlin et al., } 2015\end{array}$ & $\begin{array}{l}{[43]} \\
{[46]} \\
{[51]}\end{array}$ \\
\hline \multirow{2}{*}{$\begin{array}{l}\text { Activation of } \\
\text { angiogenesis }\end{array}$} & Increase of VEGF serum level & $\begin{array}{l}\text { Villani et al., 2016; } \\
\text { Faillaci et al., } 2018\end{array}$ & $\begin{array}{l}{[49]} \\
{[52]}\end{array}$ \\
\hline & Increase of angiopoietin-2 serum level & Faillaci et al., 2018 & [52] \\
\hline
\end{tabular}




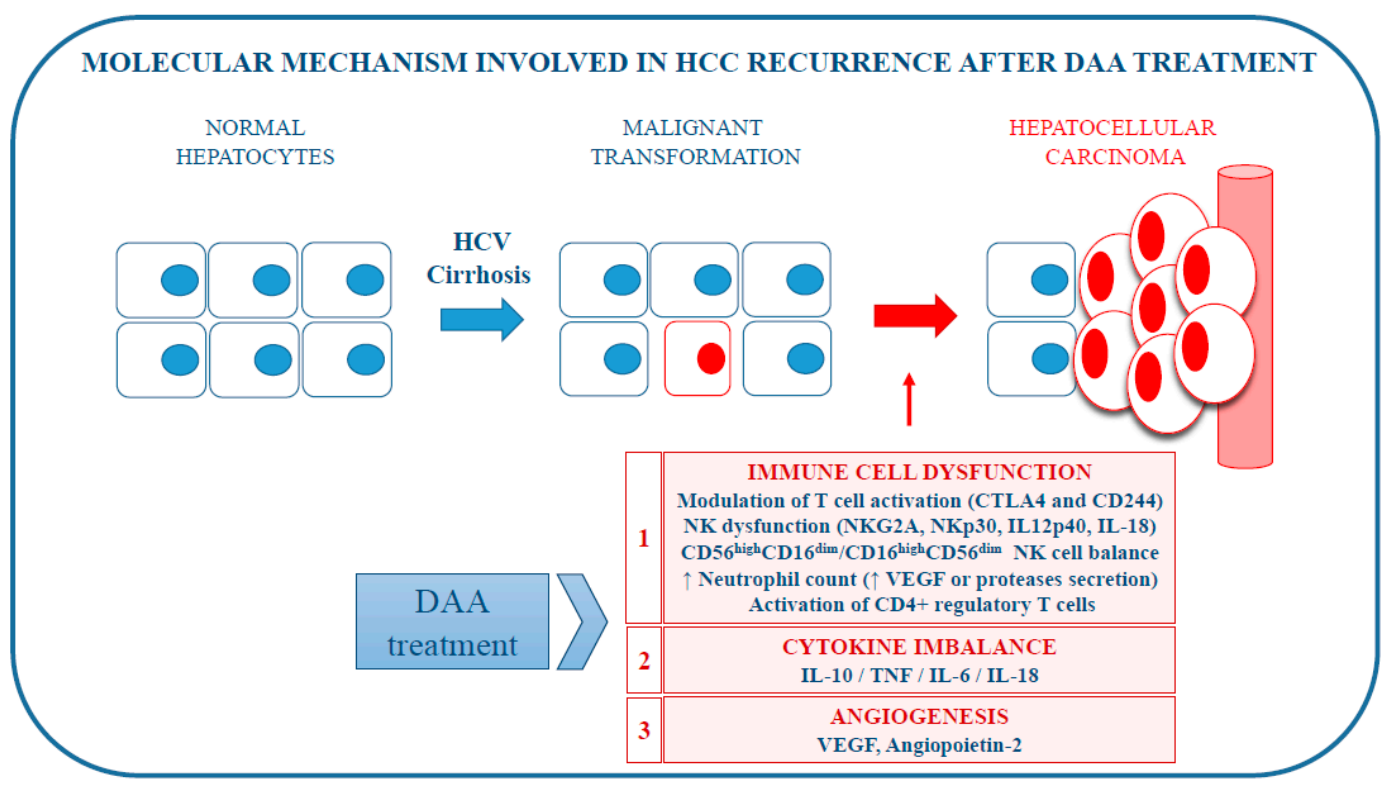

Figure 1. Molecular mechanisms potentially involved in hepatocellular carcinoma (HCC) recurrence after direct-acting antiviral (DAA) treatment for chronic HCV infection.

\section{Immune Cell Dysfunction during Chronic HCV Infection}

The immune system plays a key role both in viral clearance during acute infection and in liver injury during chronic $C$ hepatitis and, because of the lack of a cytopathic effect [53], both innate and adaptive immune responses are necessary to achieve a full recovery from viral infection [54]. However, the interaction between virus and immune system is contradictory, as HCV induces T cell exhaustion and, at the same time, it can stimulate autoantibody production [55] or cause autoimmune diseases [56] (Figure 2).

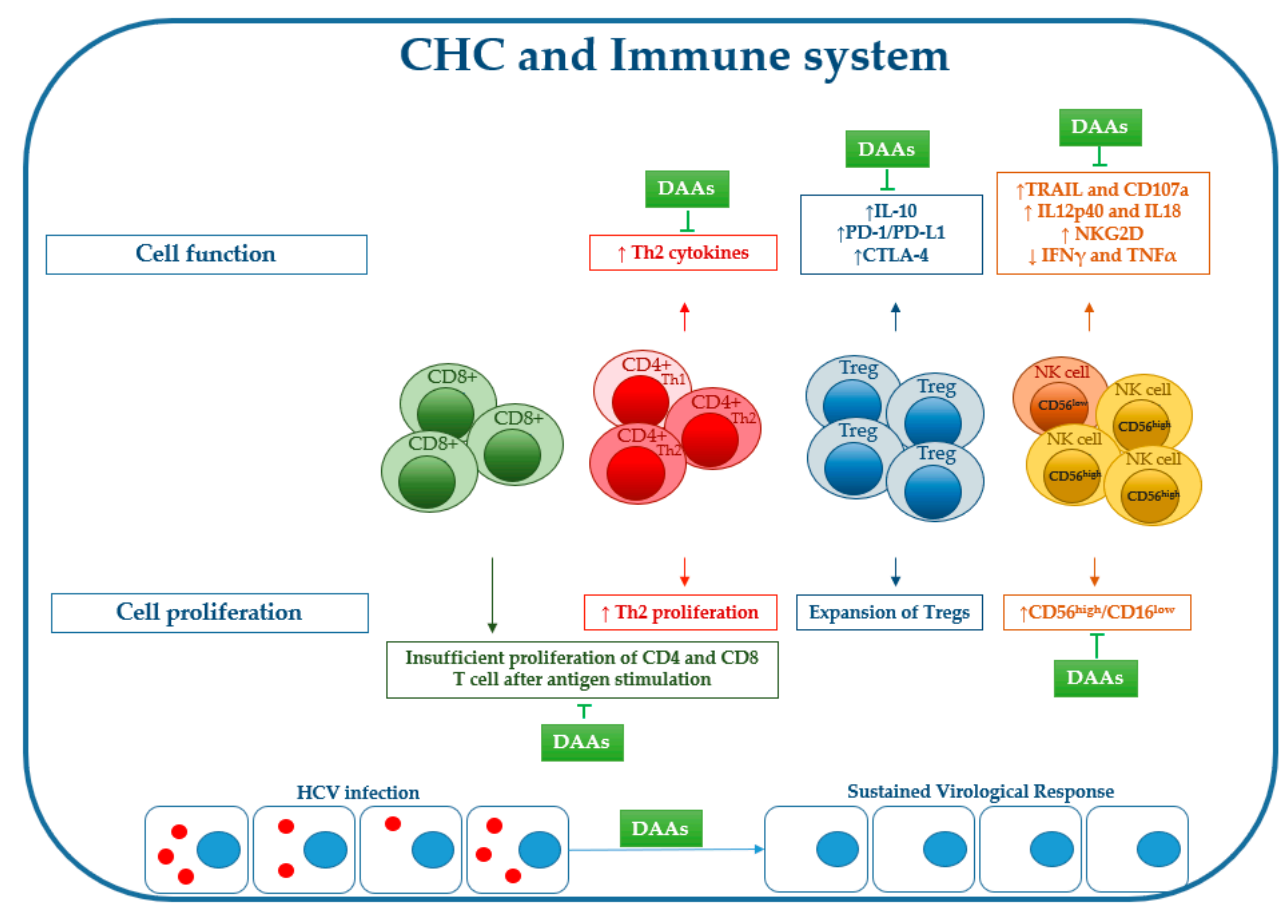

Figure 2. Effects of chronic HCV infection on immune cell proliferation/function and effect of DAA treatment on recovery of virus-induced immune changes (for explanations, see the main text). 
HCV infection is a leading cause of chronic hepatitis and liver cirrhosis, since in $70-80 \%$ of infected individuals, the virus persists after an acute phase without a spontaneous recovery [57]. Viral elimination during acute infection involves both a rapid induction of innate response and a delayed induction of adaptive immune responses.

Innate immune response is the first defense against viral infections and is maintained by interferons (IFNs) that are also able to regulate the cellular components of innate immunity, such as NK cells [58]. After viral infection and endosomal-mediated degradation of viral nucleic acids, macrophages, dendritic cells, NK, and antigen-specific $\mathrm{T}$ cells $\left(\mathrm{CD} 4^{+} \mathrm{Th} 1\right.$ and $\mathrm{CD} 8^{+}$cytotoxic $\mathrm{T}$ lymphocytes) expose viral antigens to toll-like receptors (TLRs), triggering a nonspecific antiviral response, and induce the transcription of hundreds of genes, which are distinct for different IFNs and target cell types [57].

In contrast to the innate immune response induced within hours to days after infection, adaptive immune responses (humoral antibody and $\mathrm{T}$ cells responses) become detectable not before 6- 8 weeks after viral infection [59-64]. Antibodies blocking virus binding, entry or uncoating were found in most patients with spontaneous viral clearance [65] and, similarly, a long lasting $\mathrm{CD}^{+}$and $\mathrm{CD}^{+} \mathrm{T}$ cell response targeting multiple viral epitopes persists after resolution of acute viral infection, suggesting a major role of adaptive immunity in hepatitis $C$ infection $[57,60,66-71]$.

In chronic hepatitis $\mathrm{C}, \mathrm{HCV}$ typically escapes both innate and adaptive responses [57] thanks to the release of several factors promoting viral immune evasion and globally impairing viral clearance [72], a complex immune mechanism named "T cell exhaustion", typically characterized by $\mathrm{CD} 4{ }^{+} \mathrm{T}$ cell and $\mathrm{CD}^{+} \mathrm{T}$ cell dysfunction together with impaired cytokine production and lack of response to antigen stimulation $[73,74]$.

In acute self-limiting HCV infection, circulating helper T-cells mostly produce IFN $\alpha$, suggesting Th1 predominance, whereas during chronic infection, a limited Th1-response and a prevalent Th2 response has been reported [75-77].

A critical balance between initiation and downregulation of the immune response is required for immune homeostasis and chronic inflammation and autoimmunity may result from dysfunctions of immune resolution [78].

Treatment with anti-interleukin-10 monoclonal antibody enhances IFN $\alpha$ production in HCV patients [79] and a long-term treatment with recombinant IL-10 reduces inflammation in the same patients, suggesting a pivotal role of immunosuppressive cytokine IL-10 in antiviral response and Th1/Th2 balance [75].

Experimental data have shown that a significant decline in $\mathrm{CD} 4^{+} / \mathrm{CD} 25^{+}$regulatory cells (also called Treg), typically involved in the maintenance of self-tolerance and suppression of self-reactive lymphocytes [80], is needed to induce suppression of $\mathrm{CD}^{+} \mathrm{T}$ cell proliferation and IFN- $\alpha$ production $[81,82]$. Tregs are involved in the long-term maintenance of memory $\mathrm{T}$ cells, ensuring protective immunity, and in controlling the intensity of $\mathrm{T}$ cell immune responses, even though this condition allows for inflammation to persist [80]. The presence of $\mathrm{CD} 4^{+} / \mathrm{CD} 25^{+}$depends, almost partially, on the production of immunoregulatory cytokines [75]. In contrast to natural Treg cells, which develop in the thymus and play an important role in the maintenance of self-tolerance and immune homeostasis, induced Treg cells develop from nonregulatory $\mathrm{T}$ cells in the periphery [83]. Distinct subsets of induced regulatory $\mathrm{T}$ cells have been identified, and, among those, Treg cells secreting IL-10 play a pivotal role in viral persistence [83]. During chronic hepatitis C, effector T cells become exhausted and show reduced antiviral activity, while Tregs progressively infiltrate the liver [84]. A higher frequency of Treg in HCV-infected patients was reported by several authors $[85,86]$. Similarly, Cabrera et al. reported a positive correlation between Treg frequency and HCV RNA and an inverse relation with histologic inflammatory scores, confirming a significant role of regulatory $\mathrm{T}$ cells in viral persistence [76].

Therefore, during chronic hepatitis $\mathrm{C}$, effector $\mathrm{T}$ cells become exhausted over time and show an impaired antiviral activity while $\mathrm{CD}^{+}$regulatory $\mathrm{T}$ cells (Tregs) accumulate in the liver [84]. 
Tregs are mainly regulated by interleukin (IL)-2 receptor $\alpha$ chain CD25 and Foxp3 [87]; once activated, Tregs induce expression of programmed cell death protein 1 (PD-1), programmed death-ligand 1 (PD-L1), contact-dependent regulatory molecules such as cytotoxic T-lymphocyte associated protein 4 (CTLA-4) and ultimately cytokines such as IL-10 or transforming growth factor (TGF- $\beta$ ) $[48,88,89]$. Because of their extensive role in modifying multiple immune functions, such as $\mathrm{T}$ cell responses and natural killer (NK) cells function [48], Tregs are considered to be involved in immune surveillance of tumors.

Natural killer (NK) cells are the prototype of innate lymphoid cells with potent cytolytic function that provide viral and immune surveillance against cancer [90]; two subsets of NK cells are commonly recognized: $\mathrm{CD} 56^{\text {high }} / \mathrm{CD} 16^{\text {low }}$, which mainly produce chemokines and cytokines, and CD56 ${ }^{\text {low }} / \mathrm{CD} 16^{\text {high }}$, a phenotype with prevalent cytotoxic activity [91]. Generally, NK cells are an important part of the interferon-responsive innate population in the liver ( $30 \%$ of lymphocytes) in comparison to the blood (5-20\%), and the percentage increases in viral hepatitis $[92,93]$. During chronic viral infection, they are permanently activated and polarized toward cytotoxicity with deficient IFN $\gamma$ secretion because of chronic exposure to endogenous IFN $\alpha[94,95]$. The result is a "functional dichotomy" presenting with enhanced cytolytic activity and failure to produce IFN $\gamma$ and TNF $\alpha$, with consequent inability to eradicate the virus [96]. A possible involvement of NK cells in immune surveillance of tumors might be considered [97].

\section{DAAs Are Able to Modulate Immune Cell Response}

Initial data on $\mathrm{T}$ cell function during and after direct-acting antiviral treatment were published in 2014 [98]. The authors analyzed virus-specific $\mathrm{CD} 8^{+} \mathrm{T}$ cells obtained from 51 previously untreated and chronically infected patients undergoing antiviral treatment with a combination of faldaprevir (a protease inhibitor) and deleobuvir (a non-nucleoside polymerase inhibitor) and observed a significant increase in the frequency of $\mathrm{HCV}$-specific $\mathrm{CD}^{+} \mathrm{T}$ cells within 4 weeks of therapy in patients obtaining SVR, whereas no changes were observed in patients with treatment failure. This result indicated that the immune dysfunction induced by HCV infection was reversible and that even short therapy with novel DAAs was able to restore immune capacity, whereas the same effect has never been observed in patients treated with interferons $[41,97,99,100]$.

Taken together, these first reports suggested that drugs targeted on HCV replication were able to modulate the immune system by changing $\mathrm{T}$ cell balance.

Several authors have addressed the role of NKs in chronic HCV patients during DAA therapy [93]. Before treatment, NK cells showed increased degranulation (studied by the expression of CD107a and tumor necrosis factor-related apoptosis-inducing ligand-TRAIL) and decreased production of cytokins such as IFN $\gamma$ and TNF $\alpha$; during treatment, the authors observed a decrease of NK cell-activating receptor expression together with decreased IFN $\gamma$ production followed by normalization of degranulation. Restoration of immune function induced by DAAs persisted up to the end of treatment and maintained even after suggesting that antiviral treatment is also immunologically effective [96].

These first observations were very impressive, since they did not occur during interferon therapy, where an increase in cytotoxic NK cell activity observed soon after starting therapy lasted only a few hours before leaving a refractory state [101].

In addition, Burchill et al. analyzed the composition of the memory $\mathrm{CD} 4^{+}$and $\mathrm{CD} 8^{+}$lymphocyte compartment on peripheral blood from nineteen chronic hepatitis $\mathrm{C}(\mathrm{CHC})$ patients treated with DAAs. After the rapid eradication of the virus, the frequency of NK cells was unchanged, whereas a significant reduction of the expression of PD1 on the HCV-specific T cells was found, suggesting a partial restoration in the functional capacity of HCV-specific T cells [42].

NK cell frequencies similar to healthy controls were also shown after 12 weeks of interferon-free treatment, adding new reports on the effect of viral load decline on the NK cell compartment. The frequencies of CD56 high $\mathrm{NK}$ cells $\left(\mathrm{NK}_{\text {bright }}\right.$ ) were typically higher in $\mathrm{CHC}$, whereas $\mathrm{CD} 56_{\text {low }}$ 
$\mathrm{NK}$ cell $\left(\mathrm{NK}_{\text {dim }}\right)$ frequencies were lower compared to healthy controls. After treatment with DAAs, NK cell subgroups returned to healthy control levels [43]. Cytokines involved in NK cell activation (IL-12p40 and IL-18), typically higher during chronic hepatitis C, normalized after DAA treatment [43]; the same observation was reported after interferon treatment [102]. Very interestingly, Chu et al. have reported that the pretreatment frequency of $\mathrm{CD} 56^{\text {high }} / \mathrm{CD} 16^{\mathrm{dim}} \mathrm{NK}$ cells was significantly higher and that of CD16 ${ }^{\text {high }} / \mathrm{CD} 56^{\text {dim }}$ NK cells was significantly lower in patients developing HCC after DAA treatment, showing a significant imbalance in NK cell subgroups. Moreover, the expression of NKG2D was significantly decreased during treatment, even more so in patients who developed HCC [45].

Several studies have reported a decrease of frequencies and activation of monocytes during DAA treatment [46,47], and other reports have suggested the involvement of neutrophils in the vascular endothelial growth factor (VEGF) and proteases secretion that may play a role in cancer cells spreading [44].

All these findings provide a possible rationale to support immune modification induced by DAA treatment, but further studies are needed to clarify the underlying molecular mechanism.

\section{Cytokine Network Imbalance during Chronic C Hepatitis: Effect of DAAs}

Cytokines are low-molecular-weight proteins mainly secreted by macrophages and lymphocytes and involved in cell-to-cell communication [103,104]; they also regulate proliferation, differentiation, migration, and death of immune cells [103].

A typical cytokine pattern of activated T-cell response has been described in chronic $\mathrm{HCV}$ patients, with an elevated level of serum IL-2, IL-4, TNF $\alpha$ other than IFN- $\alpha$ and IL-10 [75].

IL-10 is produced by several immune cells, including T and B cells, DC, and macrophages [105], and plays a key role as immunoregulatory molecule [72]; it suppresses antigen-presenting cells and $\mathrm{T}$ cell by inhibition of pro-inflammatory cytokine and chemokine production and, finally, by inhibition of costimulation and MHC class II expression [106-108]; moreover, viral persistence is associated with a high level of circulating DC-produced IL-10 and activation of PD-1/PD-ligand1 pathway [109-114]. In later stages, both $\mathrm{NK}$ and $\mathrm{CD} 4^{+} \mathrm{T}$ cells become the main IL-10 producers and play a pivotal role in the regulation of immune response [112,115].

A specific subset of T-cells also produces IL-10, named Tr1 [116], distinct from thymic-derived and naturally occurring CD25 $5^{+}$oxp $3^{+}$Tregs [117]. Tr1 have been found in patients with chronic HCV infection [118-120] and a subset of HCV-specific IL- $10^{+} \mathrm{CD} 8^{+} \operatorname{Tr} 1$ has been also described in the liver of such patients [121-123].

Since cytokines play a central role in the cross-talk among immune cells during chronic inflammation, some authors have suggested that modification in the circulating level of several cytokines, particularly TNF $\alpha$, IL-6, and IL-10, may contribute to cancer promotion and progression [124-126]. TNF $\alpha$ is one of the cytokines more studied in cancer and has been correlated to chronic lymphocytic leukemia, Barret's adenocarcinoma, prostate cancer, breast cancer, and cervical cancer [127-130].

A recent study has shown that, independently from HCV-RNA drop, TNF $\alpha$ remained stable or even higher in those developing HCC as compared to CHC who did not develop HCC [50], but conclusive data are lacking.

IL-6 is another cytokine which plays a significant role in the acute phase response and shows a pro-tumorigenic effect [103]; indeed, specific circulating levels are crucial for hepatocyte homeostasis because of powerful mitogen activity [131]. However, persistent activation of the IL-6 pathway in the liver is associated with the development of liver tumors [131] through a mechanism of hypermethylation of tumor suppressor genes. Very interestingly, serum IL-6 level has been reported to be increased in patients treated with DAAs and developing HCC recurrence [50].

Few data are available on the IL-18 circulating level during DAA treatment. It is considered a pro-inflammatory cytokine, synthesized and secreted by monocytes/macrophages and Kupffer cells. It activates nuclear factor (NF)- $\mathrm{kB}$, which in turn activates cell proliferation, cycle progression, 
overexpression of angiogenic genes, and apoptosis inhibition [132-134]. IL-18 is upregulated in HCV-infected patients and its receptor is commonly expressed in HCC cells.

Two studies have reported a rapid decline of serum IL-18 early after starting DAA treatment $[43,51]$ that was not confirmed by others [46]. Therefore, more data are needed to support a possible involvement of IL-18 in molecular pathway of HCC recurrence.

\section{Potential Effect of DAAs in the Modulation of Angiogenesis Signaling}

Angiogenesis is a dynamic process in which new vascular structures develop from preexisting vessels [135]. Key regulators of this process are hypoxia and inflammation, which stimulate the release of the hypoxia inducing factor (HIF), angiogenic cytokines, and growth factors from different cell types, including endothelial cells (ECs), monocytes, platelets, and smooth muscle, as well as tumor cells, and promote endothelial cell proliferation and stabilization of neovessels [135-138].

The most relevant angiogenic factor is VEGF (vascular endothelial growth factor), which has a key role in angiogenesis during inflammation and new vessel formation in tumors $[139,140]$. It is a potent growth factor produced mainly by tumor cells, macrophages, and platelets, and it is a highly specific mitogen for endothelial cells [141,142]. VEGF is activated by oncogenes and several cytokines [142] and functions as a cytokine promoting endothelial cell proliferation, vessel permeability, disruption of tight junction, and finally, the proliferative activity and the neoangiogenic potential of the tumor [143-145]. The effects of VEGF are mainly mediated in endothelial cells via VEGFR2. The activation of VEGFR2 receptor induces dilation of vessels, which also became leaky in response to VEGF signaling.

Both VEGF and Angiopoietin-2 (Ang2), a growth factor specific for the vascular endothelium and expressed during vascular remodeling in tumors [146,147], are involved in the dissolution of the vascular basement membrane and assembly into vascular networks [139] and serum concentration have been investigated to assess possible implications in liver diseases.

Hepatic neoangiogenesis has been described in liver diseases, such as viral hepatitis, cirrhosis, and HCC [148,149], and hepatitis C virus infection was found to induce production of TGF beta [137] and stabilization of HIF, resulting in the release of angiogenic cytokines [150] and proliferation of human endothelial cells [135,151].

Among the factors contributing to liver damage during chronic hepatitis $C$, angiogenesis seems to play a pivotal role $[138,149,152]$ and the degree of microvessel density is increased in HCV-positive patients [153].

The serum concentrations of VEGF and Ang2 are also increased in patients with HCC compared to patients without liver cancer [154].

We observed a rapid increase of VEGF level in patients treated with all DAA regimens. After 4 weeks of treatment, in comparison to baseline, serum VEGF remained higher until the end of treatment and returned to baseline concentration after stopping the therapy [49]. Our findings were recently confirmed by Faillaci et al., who analyzed serum liver angiopoietin-2 and VEGF levels in 242 DAA-treated patients and found a DAA-mediated increase of VEGF and angiopoietin-2 supported the increased risk of HCC recurrence/occurrence during antiviral treatment [52].

Debes et al. confirmed a potential role of VEGF in risk of hepatocellular carcinoma, but they showed an alteration of baseline serum VEGF concentration in patients who developed HCC de novo, supporting the possible pre-existing increased VEGF level without a direct role of DAAs in liver cancer [50]. Further studies are required to definitively clarify the role of DAAs on tumor recurrence.

\section{Conclusions}

DAA treatment has completely changed the natural history of chronic hepatitis $\mathrm{C}$, with the rate of cure over $90 \%$. However, some authors have reported a worrying increase in HCC recurrence. Among the pathophysiological hypotheses, the most appealing one suggests that DAAs induce dramatic HCV clearance that in turn may induce immune cell alteration, imbalance of cytokine 
network, and angiogenesis that could explain, almost in part, the HCC recurrence observed after DAAs. Data are not conclusive, and the final word remains to be said.

Acknowledgments: We are sincerely grateful to Francesca Tursi for editing the English language in the manuscript. Conflicts of Interest: The authors declare no conflict of interest.

$\begin{array}{ll}\text { Abbreviations } & \\ \text { HCC } & \text { hepatocellular carcinoma } \\ \text { CHC } & \text { chronic hepatitis C } \\ \text { NS3 } & \text { nonstructural protein 3 } \\ \text { NS5A } & \text { nonstructural protein 5A } \\ \text { TNF } \alpha & \text { tumor necrosis factor-alpha } \\ \text { NS5B } & \text { nonstructural protein 5B } \\ \text { RB1 } & \text { retinoblastoma-associated protein } \\ \text { MAVS } & \text { mitochondrial antiviral signaling protei } \\ \text { NK } & \text { natural killer } \\ \text { SVR } & \text { sustained virologic response } \\ \text { DAAs } & \text { direct-acting antivirals } \\ \text { IL12p40 } & \text { p40 subunit of IL12 } \\ \text { Treg } & \text { regulatory T cell } \\ \text { VEGF } & \text { vascular endothelial growth factor } \\ \text { IFN } & \text { interferon } \\ \text { TLR } & \text { toll-like receptor } \\ \text { IFN } \alpha & \text { interferon alpha } \\ \text { TGF } \beta & \text { transforming growth factor beta } \\ \text { PD-L1 } & \text { programmed death-ligand1 } \\ \text { CTLA-4 } & \text { cytotoxic Tl-lymphocyte associated protein 4 } \\ \text { IFN } \gamma & \text { interferon gamma } \\ \text { TRAIL } & \text { tumor necrosis factor-related apoptosis-inducing ligand } \\ \text { PD-1 } & \text { programmed death 1 } \\ \text { Ang-2 } & \text { angiopoietin } \\ \text { VEGFR2 } & \text { vascular endothelial growth factor receptor 2 } \\ \text { IL-2 } & \text { interlukin 2 } \\ \text { IL-4 } & \text { interlukin 4 } \\ \text { IL-6 } & \text { interleukin 6 } \\ \text { IL-10 } & \text { interleukin 10 } \\ \text { IL-18 } & \end{array}$

\section{References}

1. Perz, J.F.; Armstrong, G.L.; Farrington, L.A.; Hutin, Y.J.; Bell, B.P. The contributions of hepatitis B virus and hepatitis $C$ virus infections to cirrhosis and primary liver cancer worldwide. J. Hepatol. 2006, 45, 529-538. [CrossRef] [PubMed]

2. El-Serag, H.B. Epidemiology of hepatocellular carcinoma. Clin. Liver Dis. 2001, 5, 87-107. [CrossRef]

3. Torre, L.A.; Bray, F.; Siegel, R.L.; Ferlay, J.; Lortet-Tieulent, J.; Jemal, A. Global cancer statistics, 2012. CA Cancer J. Clin. 2015, 65, 87-108. [CrossRef] [PubMed]

4. Abubakar, I.I.; Tillmann, T.; Banerjee, A. Global, regional, and national age-sex specific all-cause and cause-specific mortality for 240 causes of death, 1990-2013: A systematic analysis for the Global Burden of Disease Study 2013. Lancet 2015, 385, 117-171. [CrossRef]

5. Bialecki, E.S.; Di Bisceglie, A.M. Clinical presentation and natural course of hepatocellular carcinoma. Eur. J. Gastroenterol. Hepatol. 2005, 17, 485-489. [CrossRef] [PubMed]

6. Moradpour, D.; Blum, H.E. Pathogenesis of hepatocellular carcinoma. Eur. J. Gastroenterol. Hepatol. 2005, 17, 477-483. [CrossRef] [PubMed] 
7. Fattovich, G.; Stroffolini, T.; Zagni, I.; Donato, F. Hepatocellular carcinoma in cirrhosis: Incidence and risk factors. Gastroenterology 2004, 127, S35-S50. [CrossRef] [PubMed]

8. Koike, K. Hepatitis $C$ virus contributes to hepatocarcinogenesis by modulating metabolic and intracellular signaling pathways. J. Gastroenterol. Hepatol. 2007, 22 (Suppl. S1), S108-S111. [CrossRef] [PubMed]

9. Farinati, F.; Cardin, R.; Bortolami, M.; Burra, P.; Russo, F.P.; Rugge, M.; Guido, M.; Sergio, A.; Naccarato, R. Hepatitis C virus: From oxygen free radicals to hepatocellular carcinoma. J. Viral Hepat. 2007, 14, 821-829. [CrossRef] [PubMed]

10. Hoshida, Y.; Fuchs, B.C.; Bardeesy, N.; Baumert, T.F.; Chung, R.T. Pathogenesis and prevention of hepatitis C virus-induced hepatocellular carcinoma. J. Hepatol. 2014, 61, S79-S90. [CrossRef] [PubMed]

11. Zemel, R.; Gerechet, S.; Greif, H.; Bachmatove, L.; Birk, Y.; Golan-Goldhirsh, A.; Kunin, M.; Berdichevsky, Y.; Benhar, I.; Tur-Kaspa, R. Cell transformation induced by hepatitis C virus NS3 serine protease. J. Viral Hepat. 2001, 8, 96-102. [CrossRef] [PubMed]

12. Arima, N.; Kao, C.Y.; Licht, T.; Padmanabhan, R.; Sasaguri, Y.; Padmanabhan, R. Modulation of cell growth by the hepatitis C virus nonstructural protein NS5A. J. Biol. Chem. 2001, 276, 12675-12684. [CrossRef] [PubMed]

13. Fukutomi, T.; Zhou, Y.; Kawai, S.; Eguchi, H.; Wands, J.R.; Li, J. Hepatitis C virus core protein stimulates hepatocyte growth: Correlation with upregulation of wnt-1 expression. Hepatology 2005, 41, 1096-1105. [CrossRef] [PubMed]

14. Moriya, K.; Fujie, H.; Shintani, Y.; Yotsuyanagi, H.; Tsutsumi, T.; Ishibashi, K.; Matsuura, Y.; Kimura, S.; Miyamura, T.; Koike, K. The core protein of hepatitis $\mathrm{C}$ virus induces hepatocellular carcinoma in transgenic mice. Nat. Med. 1998, 4, 1065-1067. [CrossRef] [PubMed]

15. Kao, C.F.; Chen, S.Y.; Chen, J.Y.; Wu Lee, Y.H. Modulation of p53 transcription regulatory activity and post-translational modification by hepatitis C virus core protein. Oncogene 2004, 23, 2472-2483. [CrossRef] [PubMed]

16. Alisi, A.; Giambartolomei, S.; Cupelli, F.; Merlo, P.; Fontemaggi, G.; Spaziani, A.; Balsano, C. Physical and functional interaction between HCV core protein and the different p73 isoforms. Oncogene 2003, 22, 2573-2580. [CrossRef] [PubMed]

17. Deng, L.; Nagano-Fujii, M.; Tanaka, M.; Nomura-Takigawa, Y.; Ikeda, M.; Kato, N.; Sada, K.; Hotta, H. NS3 protein of Hepatitis $\mathrm{C}$ virus associates with the tumour suppressor p53 and inhibits its function in an NS3 sequence-dependent manner. J. Gen. Virol. 2006, 87, 1703-1713. [CrossRef] [PubMed]

18. Majumder, M.; Ghosh, A.K.; Steele, R.; Ray, R.; Ray, R.B. Hepatitis C virus NS5A physically associates with p53 and regulates p21/waf1 gene expression in a p53-dependent manner. J. Virol. 2001, 75, 1401-1407. [CrossRef] [PubMed]

19. Street, A.; Macdonald, A.; McCormick, C.; Harris, M. Hepatitis C virus NS5A-mediated activation of phosphoinositide 3-kinase results in stabilization of cellular beta-catenin and stimulation of beta-catenin-responsive transcription. J. Virol. 2005, 79, 5006-5016. [CrossRef] [PubMed]

20. Ghosh, A.K.; Majumder, M.; Steele, R.; Meyer, K.; Ray, R.; Ray, R.B. Hepatitis C virus NS5A protein protects against TNF- $\alpha$ mediated apoptotic cell death. Virus Res. 2000, 67, 173-178. [CrossRef]

21. Munakata, T.; Nakamura, M.; Liang, Y.; Li, K.; Lemon, S.M. Down-regulation of the retinoblastoma tumor suppressor by the hepatitis C virus NS5B RNA-dependent RNA polymerase. Proc. Natl. Acad. Sci. USA 2005, 102, 18159-18164. [CrossRef] [PubMed]

22. Li, X.D.; Sun, L.; Seth, R.B.; Pineda, G.; Chen, Z.J. Hepatitis C virus protease NS3/4A cleaves mitochondrial antiviral signaling protein off the mitochondria to evade innate immunity. Proc. Natl. Acad. Sci. USA 2005, 102, 17717-17722. [CrossRef] [PubMed]

23. Tseng, C.T.; Klimpel, G.R. Binding of the hepatitis C virus envelope protein E2 to CD81 inhibits natural killer cell functions. J. Exp. Med. 2002, 195, 43-49. [CrossRef] [PubMed]

24. Lim, J.S.; Park, S.H.; Jang, K.L. Hepatitis C virus Core protein overcomes stress-induced premature senescence by down-regulating p16 expression via DNA methylation. Cancer Lett. 2012, 321, 154-161. [CrossRef] [PubMed]

25. van der Meer, A.J.; Veldt, B.J.; Feld, J.J.; Wedemeyer, H.; Dufour, J.F.; Lammert, F.; Duarte-Rojo, A.; Heathcote, E.J.; Manns, M.P.; Kuske, L.; et al. Association between sustained virological response and all-cause mortality among patients with chronic hepatitis $\mathrm{C}$ and advanced hepatic fibrosis. JAMA 2012, 308, 2584-2593. [CrossRef] [PubMed] 
26. Morgan, R.L.; Baack, B.; Smith, B.D.; Yartel, A.; Pitasi, M.; Falck-Ytter, Y. Eradication of hepatitis C virus infection and the development of hepatocellular carcinoma: A meta-analysis of observational studies. Ann. Intern. Med. 2013, 158, 329-337. [CrossRef] [PubMed]

27. Bourliere, M.; Bronowicki, J.P.; de Ledinghen, V.; Hezode, C.; Zoulim, F.; Mathurin, P.; Tran, A.; Larrey, D.G.; Ratziu, V.; Alric, L.; et al. Ledipasvir-sofosbuvir with or without ribavirin to treat patients with HCV genotype 1 infection and cirrhosis non-responsive to previous protease-inhibitor therapy: A randomised, double-blind, phase 2 trial (SIRIUS). Lancet Infect. Dis. 2015, 15, 397-404. [CrossRef]

28. Leroy, V.; Angus, P.; Bronowicki, J.P.; Dore, G.J.; Hezode, C.; Pianko, S.; Pol, S.; Stuart, K.; Tse, E.; McPhee, F.; et al. Daclatasvir, sofosbuvir, and ribavirin for hepatitis $C$ virus genotype 3 and advanced liver disease: A randomized phase III study (ALLY-3+). Hepatology 2016, 63, 1430-1441. [CrossRef]

29. Poordad, F.; Hezode, C.; Trinh, R.; Kowdley, K.V.; Zeuzem, S.; Agarwal, K.; Shiffman, M.L.; Wedemeyer, H.; Berg, T.; Yoshida, E.M.; et al. ABT-450/r-ombitasvir and dasabuvir with ribavirin for hepatitis C with cirrhosis. N. Engl. J. Med. 2014, 370, 1973-1982. [CrossRef]

30. Belli, L.S.; Berenguer, M.; Cortesi, P.A.; Strazzabosco, M.; Rockenschaub, S.R.; Martini, S.; Morelli, C.; Donato, F.; Volpes, R.; Pageaux, G.P.; et al. Delisting of liver transplant candidates with chronic hepatitis C after viral eradication: A European study. J. Hepatol. 2016, 65, 524-531. [CrossRef]

31. Sievert, W.; Razavi, H.; Estes, C.; Thompson, A.J.; Zekry, A.; Roberts, S.K.; Dore, G.J. Enhanced antiviral treatment efficacy and uptake in preventing the rising burden of hepatitis C-related liver disease and costs in Australia. J. Gastroenterol. Hepatol. 2014, 29 (Suppl. S1), 1-9. [CrossRef] [PubMed]

32. Conti, F.; Buonfiglioli, F.; Scuteri, A.; Crespi, C.; Bolondi, L.; Caraceni, P.; Foschi, F.G.; Lenzi, M.; Mazzella, G.; Verucchi, G.; et al. Early occurrence and recurrence of hepatocellular carcinoma in HCV-related cirrhosis treated with direct-acting antivirals. J. Hepatol. 2016, 65, 727-733. [CrossRef] [PubMed]

33. Kozbial, K.; Moser, S.; Schwarzer, R.; Laferl, H.; Al-Zoairy, R.; Stauber, R.; Stattermayer, A.F.; Beinhardt, S.; Graziadei, I.; Freissmuth, C.; et al. Unexpected high incidence of hepatocellular carcinoma in cirrhotic patients with sustained virologic response following interferon-free direct-acting antiviral treatment. J. Hepatol. 2016, 65, 856-858. [CrossRef] [PubMed]

34. Cardoso, H.; Vale, A.M.; Rodrigues, S.; Goncalves, R.; Albuquerque, A.; Pereira, P.; Lopes, S.; Silva, M.; Andrade, P.; Morais, R.; et al. High incidence of hepatocellular carcinoma following successful interferon-free antiviral therapy for hepatitis C associated cirrhosis. J. Hepatol. 2016, 65, 1070-1071. [CrossRef] [PubMed]

35. Cheung, M.C.M.; Walker, A.J.; Hudson, B.E.; Verma, S.; McLauchlan, J.; Mutimer, D.J.; Brown, A.; Gelson, W.T.H.; MacDonald, D.C.; Agarwal, K.; et al. Outcomes after successful direct-acting antiviral therapy for patients with chronic hepatitis C and decompensated cirrhosis. J. Hepatol. 2016, 65, 741-747. [CrossRef] [PubMed]

36. Reig, M.; Marino, Z.; Perello, C.; Inarrairaegui, M.; Ribeiro, A.; Lens, S.; Diaz, A.; Vilana, R.; Darnell, A.; Varela, M.; et al. Unexpected high rate of early tumor recurrence in patients with HCV-related HCC undergoing interferon-free therapy. J. Hepatol. 2016, 65, 719-726. [CrossRef] [PubMed]

37. Yang, J.D.; Aqel, B.A.; Pungpapong, S.; Gores, G.J.; Roberts, L.R.; Leise, M.D. Direct acting antiviral therapy and tumor recurrence after liver transplantation for hepatitis C-associated hepatocellular carcinoma. J. Hepatol. 2016, 65, 859-860. [CrossRef] [PubMed]

38. Zavaglia, C.; Okolicsanyi, S.; Cesarini, L.; Mazzarelli, C.; Pontecorvi, V.; Ciaccio, A.; Strazzabosco, M.; Belli, L.S. Is the risk of neoplastic recurrence increased after prescribing direct-acting antivirals for $\mathrm{HCV}$ patients whose HCC was previously cured? J. Hepatol. 2017, 66, 236-237. [CrossRef]

39. Minami, T.; Tateishi, R.; Nakagomi, R.; Fujiwara, N.; Sato, M.; Enooku, K.; Nakagawa, H.; Asaoka, Y.; Kondo, Y.; Shiina, S.; et al. The impact of direct-acting antivirals on early tumor recurrence after radiofrequency ablation in hepatitis C-related hepatocellular carcinoma. J. Hepatol. 2016, 65, 1272-1273. [CrossRef]

40. Nault, J.C.; Colombo, M. Hepatocellular carcinoma and direct acting antiviral treatments: Controversy after the revolution. J. Hepatol. 2016, 65, 663-665. [CrossRef]

41. Meissner, E.G.; Wu, D.; Osinusi, A.; Bon, D.; Virtaneva, K.; Sturdevant, D.; Porcella, S.; Wang, H.; Herrmann, E.; McHutchison, J.; et al. Endogenous intrahepatic IFNs and association with IFN-free HCV treatment outcome. J. Clin. Investig. 2014, 124, 3352-3363. [CrossRef] [PubMed] 
42. Burchill, M.A.; Golden-Mason, L.; Wind-Rotolo, M.; Rosen, H.R. Memory re-differentiation and reduced lymphocyte activation in chronic HCV-infected patients receiving direct-acting antivirals. J. Viral Hepat. 2015, 22, 983-991. [CrossRef] [PubMed]

43. Spaan, M.; van Oord, G.; Kreefft, K.; Hou, J.; Hansen, B.E.; Janssen, H.L.; de Knegt, R.J.; Boonstra, A. Immunological Analysis During Interferon-Free Therapy for Chronic Hepatitis C Virus Infection Reveals Modulation of the Natural Killer Cell Compartment. J. Infect. Dis. 2016, 213, 216-223. [CrossRef] [PubMed]

44. Casadei Gardini, A.; Conti, F.; Foschi, F.G.; Brillanti, S.; Andreone, P.; Mazzella, G.; Ravaioli, F. Imbalance of Neutrophils and Lymphocyte Counts Can Be Predictive of Hepatocellular Carcinoma Occurrence in Hepatitis C-related Cirrhosis Treated With Direct-acting Antivirals. Gastroenterology 2018, 154, 2281-2282. [CrossRef] [PubMed]

45. Chu, P.S.; Nakamoto, N.; Taniki, N.; Ojiro, K.; Amiya, T.; Makita, Y.; Murata, H.; Yamaguchi, A.; Shiba, S.; Miyake, R.; et al. On-treatment decrease of NKG2D correlates to early emergence of clinically evident hepatocellular carcinoma after interferon-free therapy for chronic hepatitis C. PLoS ONE 2017, 12, e0179096. [CrossRef] [PubMed]

46. Ning, G.; Li, Y.T.; Chen, Y.M.; Zhang, Y.; Zeng, Y.F.; Lin, C.S. Dynamic Changes of the Frequency of Classic and Inflammatory Monocytes Subsets and Natural Killer Cells in Chronic Hepatitis C Patients Treated by Direct-Acting Antiviral Agents. Can. J. Gastroenterol. Hepatol. 2017, 2017, 3612403. [CrossRef]

47. Meissner, E.G.; Kohli, A.; Higgins, J.; Lee, Y.J.; Prokunina, O.; Wu, D.; Orr, C.; Masur, H.; Kottilil, S. Rapid changes in peripheral lymphocyte concentrations during interferon-free treatment of chronic hepatitis C virus infection. Hepatol. Commun. 2017, 1, 586-594. [CrossRef]

48. Langhans, B.; Nischalke, H.D.; Kramer, B.; Hausen, A.; Dold, L.; van Heteren, P.; Huneburg, R.; Nattermann, J.; Strassburg, C.P.; Spengler, U. Increased peripheral CD4(+) regulatory T cells persist after successful direct-acting antiviral treatment of chronic hepatitis C. J. Hepatol. 2017, 66, 888-896. [CrossRef]

49. Villani, R.; Facciorusso, A.; Bellanti, F.; Tamborra, R.; Piscazzi, A.; Landriscina, M.; Vendemiale, G.; Serviddio, G. DAAs Rapidly Reduce Inflammation but Increase Serum VEGF Level: A Rationale for Tumor Risk during Anti-HCV Treatment. PLoS ONE 2016, 11, e0167934. [CrossRef]

50. Debes, J.D.; van Tilborg, M.; Groothuismink, Z.M.A.; Hansen, B.E.; Schulze Zur Wiesch, J.; von Felden, J.; de Knegt, R.J.; Boonstra, A. Levels of Cytokines in Serum Associate With Development of Hepatocellular Carcinoma in Patients With HCV Infection Treated With Direct-Acting Antivirals. Gastroenterology 2018, 154, 515-517. [CrossRef]

51. Carlin, A.F.; Aristizabal, P.; Song, Q.; Wang, H.; Paulson, M.S.; Stamm, L.M.; Schooley, R.T.; Wyles, D.L. Temporal dynamics of inflammatory cytokines/chemokines during sofosbuvir and ribavirin therapy for genotype 2 and 3 hepatitis C infection. Hepatology 2015, 62, 1047-1058. [CrossRef] [PubMed]

52. Faillaci, F.; Marzi, L.; Critelli, R.; Milosa, F.; Schepis, F.; Turola, E.; Andreani, S.; Vandelli, G.; Bernabucci, V.; Lei, B.; et al. Liver Angiopoietin-2 is a key predictor of de novo or recurrent hepatocellular cancer after HCV direct-acting antivirals. Hepatology 2018. [CrossRef] [PubMed]

53. Koziel, M.J. Cellular immune responses against hepatitis C virus. Clin. Infect. Dis. 2005, 41 (Suppl. S1), S25-S31. [CrossRef] [PubMed]

54. Terilli, R.R.; Cox, A.L. Immunity and hepatitis C: A review. Curr. HIV/AIDS Rep. 2013, 10, 51-58. [CrossRef]

55. Rigopoulou, E.I.; Zachou, K.; Gatselis, N.; Koukoulis, G.K.; Dalekos, G.N. Autoimmune hepatitis in patients with chronic HBV and HCV infections: Patterns of clinical characteristics, disease progression and outcome. Ann. Hepatol. 2013, 13, 127-135. [PubMed]

56. Strassburg, C.P.; Vogel, A.; Manns, M.P. Autoimmunity and hepatitis C. Autoimmun. Rev. 2003, 2, 322-331. [CrossRef]

57. Heim, M.H.; Thimme, R. Innate and adaptive immune responses in HCV infections. J. Hepatol. 2014, 61, S14-S25. [CrossRef]

58. Stetson, D.B.; Medzhitov, R. Type I interferons in host defense. Immunity 2006, 25, 373-381. [CrossRef]

59. Su, A.I.; Pezacki, J.P.; Wodicka, L.; Brideau, A.D.; Supekova, L.; Thimme, R.; Wieland, S.; Bukh, J.; Purcell, R.H.; Schultz, P.G.; et al. Genomic analysis of the host response to hepatitis $C$ virus infection. Proc. Natl. Acad. Sci. USA 2002, 99, 15669-15674. [CrossRef]

60. Thimme, R.; Bukh, J.; Spangenberg, H.C.; Wieland, S.; Pemberton, J.; Steiger, C.; Govindarajan, S.; Purcell, R.H.; Chisari, F.V. Viral and immunological determinants of hepatitis $C$ virus clearance, persistence, and disease. Proc. Natl. Acad. Sci. USA 2002, 99, 15661-15668. [CrossRef] 
61. Rehermann, B. Pathogenesis of chronic viral hepatitis: Differential roles of T cells and NK cells. Nat. Med. 2013, 19, 859-868. [CrossRef] [PubMed]

62. Thimme, R.; Binder, M.; Bartenschlager, R. Failure of innate and adaptive immune responses in controlling hepatitis C virus infection. FEMS Microbiol. Rev. 2012, 36, 663-683. [CrossRef] [PubMed]

63. Shin, E.C.; Park, S.H.; Demino, M.; Nascimbeni, M.; Mihalik, K.; Major, M.; Veerapu, N.S.; Heller, T.; Feinstone, S.M.; Rice, C.M.; et al. Delayed induction, not impaired recruitment, of specific CD8(+) T cells causes the late onset of acute hepatitis C. Gastroenterology 2011, 141, 686-695. [CrossRef] [PubMed]

64. Klenerman, P.; Thimme, R. T cell responses in hepatitis C: The good, the bad and the unconventional. Gut 2012, 61, 1226-1234. [CrossRef] [PubMed]

65. Pestka, J.M.; Zeisel, M.B.; Blaser, E.; Schurmann, P.; Bartosch, B.; Cosset, F.L.; Patel, A.H.; Meisel, H.; Baumert, J.; Viazov, S.; et al. Rapid induction of virus-neutralizing antibodies and viral clearance in a single-source outbreak of hepatitis C. Proc. Natl. Acad. Sci. USA 2007, 104, 6025-6030. [CrossRef] [PubMed]

66. Thimme, R.; Oldach, D.; Chang, K.M.; Steiger, C.; Ray, S.C.; Chisari, F.V. Determinants of viral clearance and persistence during acute hepatitis C virus infection. J. Exp. Med. 2001, 194, 1395-1406. [CrossRef] [PubMed]

67. Cooper, S.; Erickson, A.L.; Adams, E.J.; Kansopon, J.; Weiner, A.J.; Chien, D.Y.; Houghton, M.; Parham, P.; Walker, C.M. Analysis of a successful immune response against hepatitis C virus. Immunity 1999, 10, 439-449. [CrossRef]

68. Takaki, A.; Wiese, M.; Maertens, G.; Depla, E.; Seifert, U.; Liebetrau, A.; Miller, J.L.; Manns, M.P.; Rehermann, B. Cellular immune responses persist and humoral responses decrease two decades after recovery from a single-source outbreak of hepatitis C. Nat. Med. 2000, 6, 578-582. [CrossRef]

69. Diepolder, H.M.; Gerlach, J.T.; Zachoval, R.; Hoffmann, R.M.; Jung, M.C.; Wierenga, E.A.; Scholz, S.; Santantonio, T.; Houghton, M.; Southwood, S.; et al. Immunodominant CD4+ T-cell epitope within nonstructural protein 3 in acute hepatitis C virus infection. J. Virol. 1997, 71, 6011-6019.

70. Lechner, F.; Wong, D.K.; Dunbar, P.R.; Chapman, R.; Chung, R.T.; Dohrenwend, P.; Robbins, G.; Phillips, R.; Klenerman, P.; Walker, B.D. Analysis of successful immune responses in persons infected with hepatitis C virus. J. Exp. Med. 2000, 191, 1499-1512. [CrossRef]

71. Missale, G.; Bertoni, R.; Lamonaca, V.; Valli, A.; Massari, M.; Mori, C.; Rumi, M.G.; Houghton, M.; Fiaccadori, F.; Ferrari, C. Different clinical behaviors of acute hepatitis C virus infection are associated with different vigor of the anti-viral cell-mediated immune response. J. Clin. Investig. 1996, 98, 706-714. [CrossRef] [PubMed]

72. Rojas, J.M.; Avia, M.; Martin, V.; Sevilla, N. IL-10: A Multifunctional Cytokine in Viral Infections. J. Immunol. Res. 2017, 2017, 6104054. [CrossRef] [PubMed]

73. Brooks, D.G.; Teyton, L.; Oldstone, M.B.; McGavern, D.B. Intrinsic functional dysregulation of CD4 T cells occurs rapidly following persistent viral infection. J. Virol. 2005, 79, 10514-10527. [CrossRef] [PubMed]

74. Wherry, E.J. T cell exhaustion. Nat. Immunol. 2011, 12, 492-499. [CrossRef] [PubMed]

75. Nelson, D.R.; Tu, Z.; Soldevila-Pico, C.; Abdelmalek, M.; Zhu, H.; Xu, Y.L.; Cabrera, R.; Liu, C.; Davis, G.L. Long-term interleukin 10 therapy in chronic hepatitis $\mathrm{C}$ patients has a proviral and anti-inflammatory effect. Hepatology 2003, 38, 859-868. [CrossRef] [PubMed]

76. Cabrera, R.; Tu, Z.; Xu, Y.; Firpi, R.J.; Rosen, H.R.; Liu, C.; Nelson, D.R. An immunomodulatory role for CD4(+)CD25(+) regulatory T lymphocytes in hepatitis C virus infection. Hepatology 2004, 40, 1062-1071. [CrossRef] [PubMed]

77. Tsai, S.L.; Liaw, Y.F.; Chen, M.H.; Huang, C.Y.; Kuo, G.C. Detection of type 2-like T-helper cells in hepatitis C virus infection: Implications for hepatitis C virus chronicity. Hepatology 1997, 25, 449-458. [CrossRef]

78. Tuma, R.A.; Pamer, E.G. Homeostasis of naive, effector and memory CD8 T cells. Curr. Opin. Immunol. 2002, 14, 348-353. [CrossRef]

79. Piazzolla, G.; Tortorella, C.; Schiraldi, O.; Antonaci, S. Relationship between interferon-gamma, interleukin-10, and interleukin-12 production in chronic hepatitis $C$ and in vitro effects of interferon-alpha. J. Clin. Immunol. 2000, 20, 54-61. [CrossRef]

80. Sakaguchi, S. Regulatory T cells: Mediating compromises between host and parasite. Nat. Immunol. 2003, 4, 10-11. [CrossRef]

81. Sakaguchi, S. Regulatory T cells: Key controllers of immunologic self-tolerance. Cell 2000, 101, 455-458. [CrossRef] 
82. Piccirillo, C.A.; Shevach, E.M. Cutting edge: Control of CD8+ T cell activation by CD4+CD25+ immunoregulatory cells. J. Immunol. 2001, 167, 1137-1140. [CrossRef]

83. Billerbeck, E.; Bottler, T.; Thimme, R. Regulatory T cells in viral hepatitis. World J. Gastroenterol. 2007, 13, $4858-4864$. [CrossRef]

84. Barjon, C.; Dahlqvist, G.; Calmus, Y.; Conti, F. Role of regulatory T-cells during hepatitis C infection: From the acute phase to post-transplantation recurrence. Dig. Liver Dis. 2015, 47, 913-917. [CrossRef]

85. Sugimoto, K.; Ikeda, F.; Stadanlick, J.; Nunes, F.A.; Alter, H.J.; Chang, K.M. Suppression of HCV-specific T cells without differential hierarchy demonstrated ex vivo in persistent HCV infection. Hepatology 2003, 38, 1437-1448. [CrossRef] [PubMed]

86. Rushbrook, S.M.; Ward, S.M.; Unitt, E.; Vowler, S.L.; Lucas, M.; Klenerman, P.; Alexander, G.J. Regulatory T cells suppress in vitro proliferation of virus-specific $\mathrm{CD} 8+\mathrm{T}$ cells during persistent hepatitis $\mathrm{C}$ virus infection. J. Virol. 2005, 79, 7852-7859. [CrossRef] [PubMed]

87. Shevach, E.M.; Thornton, A.M. tTregs, pTregs, and iTregs: Similarities and differences. Immunol. Rev. 2014, 259, 88-102. [CrossRef] [PubMed]

88. Wang, F.; Wan, L.; Zhang, C.; Zheng, X.; Li, J.; Chen, Z.K. Tim-3-Galectin-9 pathway involves the suppression induced by CD4+CD25+ regulatory T cells. Immunobiology 2009, 214, 342-349. [CrossRef]

89. Dilek, N.; Poirier, N.; Hulin, P.; Coulon, F.; Mary, C.; Ville, S.; Vie, H.; Clemenceau, B.; Blancho, G.; Vanhove, B. Targeting CD28, CTLA-4 and PD-L1 costimulation differentially controls immune synapses and function of human regulatory and conventional T-cells. PLoS ONE 2013, 8, e83139. [CrossRef]

90. Morvan, M.G.; Lanier, L.L. NK cells and cancer: You can teach innate cells new tricks. Nat. Rev. Cancer 2016, 16, 7-19. [CrossRef]

91. Chiu, J.; Ernst, D.M.; Keating, A. Acquired Natural Killer Cell Dysfunction in the Tumor Microenvironment of Classic Hodgkin Lymphoma. Front. Immunol. 2018, 9, 267. [CrossRef]

92. Doherty, D.G.; O’Farrelly, C. Innate and adaptive lymphoid cells in the human liver. Immunol. Rev. 2000, 174, 5-20. [CrossRef]

93. Serti, E.; Chepa-Lotrea, X.; Kim, Y.J.; Keane, M.; Fryzek, N.; Liang, T.J.; Ghany, M.; Rehermann, B. Successful Interferon-Free Therapy of Chronic Hepatitis C Virus Infection Normalizes Natural Killer Cell Function. Gastroenterology 2015, 149, 190-200. [CrossRef] [PubMed]

94. Oliviero, B.; Varchetta, S.; Paudice, E.; Michelone, G.; Zaramella, M.; Mavilio, D.; De Filippi, F.; Bruno, S.; Mondelli, M.U. Natural killer cell functional dichotomy in chronic hepatitis B and chronic hepatitis $C$ virus infections. Gastroenterology 2009, 137, 1151-1160. [CrossRef] [PubMed]

95. Ahlenstiel, G.; Titerence, R.H.; Koh, C.; Edlich, B.; Feld, J.J.; Rotman, Y.; Ghany, M.G.; Hoofnagle, J.H.; Liang, T.J.; Heller, T.; et al. Natural killer cells are polarized toward cytotoxicity in chronic hepatitis C in an interferon-alfa-dependent manner. Gastroenterology 2010, 138, 325-335. [CrossRef] [PubMed]

96. Mondelli, M.U. Direct-Acting Antivirals Cure Innate Immunity in Chronic Hepatitis C. Gastroenterology 2015, 149, 25-28. [CrossRef]

97. Missale, G.; Pilli, M.; Zerbini, A.; Penna, A.; Ravanetti, L.; Barili, V.; Orlandini, A.; Molinari, A.; Fasano, M.; Santantonio, T.; et al. Lack of full CD8 functional restoration after antiviral treatment for acute and chronic hepatitis C virus infection. Gut 2012, 61, 1076-1084. [CrossRef]

98. Martin, B.; Hennecke, N.; Lohmann, V.; Kayser, A.; Neumann-Haefelin, C.; Kukolj, G.; Bocher, W.O.; Thimme, R. Restoration of HCV-specific CD8+ T cell function by interferon-free therapy. J. Hepatol. 2014, 61, 538-543. [CrossRef]

99. Abdel-Hakeem, M.S.; Bedard, N.; Badr, G.; Ostrowski, M.; Sekaly, R.P.; Bruneau, J.; Willems, B.; Heathcote, E.J.; Shoukry, N.H. Comparison of immune restoration in early versus late alpha interferon therapy against hepatitis C virus. J. Virol. 2010, 84, 10429-10435. [CrossRef]

100. Seigel, B.; Bengsch, B.; Lohmann, V.; Bartenschlager, R.; Blum, H.E.; Thimme, R. Factors that determine the antiviral efficacy of HCV-specific CD8(+) T cells ex vivo. Gastroenterology 2013, 144, 426-436. [CrossRef]

101. Ahlenstiel, G. The natural killer cell response to HCV infection. Immune Netw. 2013, 13, 168-176. [CrossRef] [PubMed]

102. Kaser, A.; Novick, D.; Rubinstein, M.; Siegmund, B.; Enrich, B.; Koch, R.O.; Vogel, W.; Kim, S.H.; Dinarello, C.A.; Tilg, H. Interferon-alpha induces interleukin-18 binding protein in chronic hepatitis C patients. Clin. Exp. Immunol. 2002, 129, 332-338. [CrossRef] [PubMed] 
103. Landskron, G.; De la Fuente, M.; Thuwajit, P.; Thuwajit, C.; Hermoso, M.A. Chronic inflammation and cytokines in the tumor microenvironment. J. Immunol. Res. 2014, 2014, 149185. [CrossRef] [PubMed]

104. Arango Duque, G.; Descoteaux, A. Macrophage cytokines: Involvement in immunity and infectious diseases. Front. Immunol. 2014, 5, 491. [CrossRef] [PubMed]

105. Blackburn, S.D.; Wherry, E.J. IL-10, T cell exhaustion and viral persistence. Trends Microbiol. 2007, 15, $143-146$. [CrossRef] [PubMed]

106. Moore, K.W.; O'Garra, A.; de Waal Malefyt, R.; Vieira, P.; Mosmann, T.R. Interleukin-10. Annu. Rev. Immunol. 1993, 11, 165-190. [CrossRef] [PubMed]

107. Pestka, S.; Krause, C.D.; Sarkar, D.; Walter, M.R.; Shi, Y.; Fisher, P.B. Interleukin-10 and related cytokines and receptors. Annu. Rev. Immunol. 2004, 22, 929-979. [CrossRef]

108. Ejrnaes, M.; Filippi, C.M.; Martinic, M.M.; Ling, E.M.; Togher, L.M.; Crotty, S.; von Herrath, M.G. Resolution of a chronic viral infection after interleukin-10 receptor blockade. J. Exp. Med. 2006, 203, 2461-2472. [CrossRef]

109. Snell, L.M.; Osokine, I.; Yamada, D.H.; De la Fuente, J.R.; Elsaesser, H.J.; Brooks, D.G. Overcoming CD4 Th1 Cell Fate Restrictions to Sustain Antiviral CD8 T Cells and Control Persistent Virus Infection. Cell Rep. 2016, 16, 3286-3296. [CrossRef]

110. Barber, D.L.; Wherry, E.J.; Masopust, D.; Zhu, B.; Allison, J.P.; Sharpe, A.H.; Freeman, G.J.; Ahmed, R. Restoring function in exhausted CD8 T cells during chronic viral infection. Nature 2006, 439, 682-687. [CrossRef]

111. Flynn, J.K.; Dore, G.J.; Hellard, M.; Yeung, B.; Rawlinson, W.D.; White, P.A.; Kaldor, J.M.; Lloyd, A.R.; Ffrench, R.A.; Group, A.S. Early IL-10 predominant responses are associated with progression to chronic hepatitis $C$ virus infection in injecting drug users. J. Viral Hepat. 2011, 18, 549-561. [CrossRef] [PubMed]

112. De Maria, A.; Fogli, M.; Mazza, S.; Basso, M.; Picciotto, A.; Costa, P.; Congia, S.; Mingari, M.C.; Moretta, L. Increased natural cytotoxicity receptor expression and relevant IL-10 production in NK cells from chronically infected viremic HCV patients. Eur. J. Immunol. 2007, 37, 445-455. [CrossRef] [PubMed]

113. Brockman, M.A.; Kwon, D.S.; Tighe, D.P.; Pavlik, D.F.; Rosato, P.C.; Sela, J.; Porichis, F.; Le Gall, S.; Waring, M.T.; Moss, K.; et al. IL-10 is up-regulated in multiple cell types during viremic HIV infection and reversibly inhibits virus-specific T cells. Blood 2009, 114, 346-356. [CrossRef] [PubMed]

114. Said, E.A.; Dupuy, F.P.; Trautmann, L.; Zhang, Y.; Shi, Y.; El-Far, M.; Hill, B.J.; Noto, A.; Ancuta, P.; Peretz, Y.; et al. Programmed death-1-induced interleukin-10 production by monocytes impairs CD4+ T cell activation during HIV infection. Nat. Med. 2010, 16, 452-459. [CrossRef] [PubMed]

115. Parish, I.A.; Marshall, H.D.; Staron, M.M.; Lang, P.A.; Brustle, A.; Chen, J.H.; Cui, W.; Tsui, Y.C.; Perry, C.; Laidlaw, B.J.; et al. Chronic viral infection promotes sustained Th1-derived immunoregulatory IL-10 via BLIMP-1. J. Clin. Investig. 2014, 124, 3455-3468. [CrossRef] [PubMed]

116. Groux, H.; O'Garra, A.; Bigler, M.; Rouleau, M.; Antonenko, S.; de Vries, J.E.; Roncarolo, M.G. A CD4+ T-cell subset inhibits antigen-specific T-cell responses and prevents colitis. Nature 1997, 389, 737-742. [CrossRef] [PubMed]

117. Sakaguchi, S. The origin of FOXP3-expressing CD4+ regulatory T cells: Thymus or periphery. J. Clin. Investig. 2003, 112, 1310-1312. [CrossRef]

118. Ulsenheimer, A.; Gerlach, J.T.; Gruener, N.H.; Jung, M.C.; Schirren, C.A.; Schraut, W.; Zachoval, R.; Pape, G.R.; Diepolder, H.M. Detection of functionally altered hepatitis $C$ virus-specific CD4 T cells in acute and chronic hepatitis C. Hepatology 2003, 37, 1189-1198. [CrossRef]

119. MacDonald, A.J.; Duffy, M.; Brady, M.T.; McKiernan, S.; Hall, W.; Hegarty, J.; Curry, M.; Mills, K.H. CD4 T helper type 1 and regulatory $\mathrm{T}$ cells induced against the same epitopes on the core protein in hepatitis $\mathrm{C}$ virus-infected persons. J. Infect. Dis. 2002, 185, 720-727. [CrossRef]

120. Graham, C.S.; Wells, A.; Liu, T.; Sherman, K.E.; Peters, M.; Chung, R.T.; Bhan, A.K.; Andersen, J.; Koziel, M.J.; Team, A.S. Antigen-specific immune responses and liver histology in HIV and hepatitis C coinfection. AIDS 2005, 19, 767-773. [CrossRef]

121. Kaplan, D.E.; Ikeda, F.; Li, Y.; Nakamoto, N.; Ganesan, S.; Valiga, M.E.; Nunes, F.A.; Rajender Reddy, K.; Chang, K.M. Peripheral virus-specific T-cell interleukin-10 responses develop early in acute hepatitis C infection and become dominant in chronic hepatitis. J. Hepatol. 2008, 48, 903-913. [CrossRef] [PubMed] 
122. Abel, M.; Sene, D.; Pol, S.; Bourliere, M.; Poynard, T.; Charlotte, F.; Cacoub, P.; Caillat-Zucman, S. Intrahepatic virus-specific IL-10-producing CD8 T cells prevent liver damage during chronic hepatitis C virus infection. Hepatology 2006, 44, 1607-1616. [CrossRef] [PubMed]

123. Accapezzato, D.; Francavilla, V.; Paroli, M.; Casciaro, M.; Chircu, L.V.; Cividini, A.; Abrignani, S.; Mondelli, M.U.; Barnaba, V. Hepatic expansion of a virus-specific regulatory CD8(+) T cell population in chronic hepatitis C virus infection. J. Clin. Investig. 2004, 113, 963-972. [CrossRef] [PubMed]

124. Zamarron, B.F.; Chen, W. Dual roles of immune cells and their factors in cancer development and progression. Int. J. Biol. Sci. 2011, 7, 651-658. [CrossRef] [PubMed]

125. Jang, J.W.; Oh, B.S.; Kwon, J.H.; You, C.R.; Chung, K.W.; Kay, C.S.; Jung, H.S. Serum interleukin-6 and C-reactive protein as a prognostic indicator in hepatocellular carcinoma. Cytokine 2012, 60, 686-693. [CrossRef] [PubMed]

126. Wang, H.; Liu, J.; Hu, X.; Liu, S.; He, B. Prognostic and Therapeutic Values of Tumor Necrosis Factor-Alpha in Hepatocellular Carcinoma. Med. Sci. Monit. 2016, 22, 3694-3704. [CrossRef] [PubMed]

127. Ferrajoli, A.; Keating, M.J.; Manshouri, T.; Giles, F.J.; Dey, A.; Estrov, Z.; Koller, C.A.; Kurzrock, R.; Thomas, D.A.; Faderl, S.; et al. The clinical significance of tumor necrosis factor-alpha plasma level in patients having chronic lymphocytic leukemia. Blood 2002, 100, 1215-1219.

128. Ahmed, M.I.; Salahy, E.E.; Fayed, S.T.; El-Hefnawy, N.G.; Khalifa, A. Human papillomavirus infection among Egyptian females with cervical carcinoma: Relationship to spontaneous apoptosis and TNF-alpha. Clin. Biochem. 2001, 34, 491-498. [CrossRef]

129. Szlosarek, P.W.; Grimshaw, M.J.; Kulbe, H.; Wilson, J.L.; Wilbanks, G.D.; Burke, F.; Balkwill, F.R. Expression and regulation of tumor necrosis factor alpha in normal and malignant ovarian epithelium. Mol. Cancer Ther. 2006, 5, 382-390. [CrossRef]

130. Wang, X.; Lin, Y. Tumor necrosis factor and cancer, buddies or foes? Acta Pharmacol. Sin. 2008, 29, 1275-1288. [CrossRef]

131. Schmidt-Arras, D.; Rose-John, S. IL-6 pathway in the liver: From physiopathology to therapy. J. Hepatol. 2016, 64, 1403-1415. [CrossRef] [PubMed]

132. Asakawa, M.; Kono, H.; Amemiya, H.; Matsuda, M.; Suzuki, T.; Maki, A.; Fujii, H. Role of interleukin-18 and its receptor in hepatocellular carcinoma associated with hepatitis $\mathrm{C}$ virus infection. Int. J. Cancer 2006, 118, 564-570. [CrossRef] [PubMed]

133. Okamura, H.; Tsutsi, H.; Komatsu, T.; Yutsudo, M.; Hakura, A.; Tanimoto, T.; Torigoe, K.; Okura, T.; Nukada, Y.; Hattori, K.; et al. Cloning of a new cytokine that induces IFN-gamma production by T cells. Nature 1995, 378, 88-91. [CrossRef] [PubMed]

134. Li, X.; Stark, G.R. NFkappaB-dependent signaling pathways. Exp. Hematol. 2002, 30, 285-296. [CrossRef]

135. Hassan, M.; Selimovic, D.; El-Khattouti, A.; Soell, M.; Ghozlan, H.; Haikel, Y.; Abdelkader, O.; Megahed, M. Hepatitis C virus-mediated angiogenesis: Molecular mechanisms and therapeutic strategies. World J. Gastroenterol. 2014, 20, 15467-15475. [CrossRef] [PubMed]

136. Tandle, A.; Blazer, D.G., III; Libutti, S.K. Antiangiogenic gene therapy of cancer: Recent developments. J. Transl. Med. 2004, 2, 22. [CrossRef] [PubMed]

137. Hassan, M.; Selimovic, D.; Ghozlan, H.; Abdel-kader, O. Hepatitis C virus core protein triggers hepatic angiogenesis by a mechanism including multiple pathways. Hepatology 2009, 49, 1469-1482. [CrossRef]

138. Salcedo, X.; Medina, J.; Sanz-Cameno, P.; Garcia-Buey, L.; Martin-Vilchez, S.; Borque, M.J.; Lopez-Cabrera, M.; Moreno-Otero, R. The potential of angiogenesis soluble markers in chronic hepatitis C. Hepatology 2005, 42, 696-701. [CrossRef]

139. Zhu, A.X.; Duda, D.G.; Sahani, D.V.; Jain, R.K. HCC and angiogenesis: Possible targets and future directions. Nat. Rev. Clin. Oncol. 2011, 8, 292-301. [CrossRef]

140. Elpek, G.O. Angiogenesis and liver fibrosis. World J. Hepatol. 2015, 7, 377-391. [CrossRef]

141. Duffy, A.M.; Bouchier-Hayes, D.J.; Harmey, J.H. Vascular Endothelial Growth Factor (VEGF) and Its Role in Non-Endothelial Cells: Autocrine Signalling by VEGF. In Madame Curie Bioscience Database; Landes Bioscience: Austin, TX, USA, 2013.

142. Neufeld, G.; Cohen, T.; Gengrinovitch, S.; Poltorak, Z. Vascular endothelial growth factor (VEGF) and its receptors. FASEB J. 1999, 13, 9-22. [CrossRef] [PubMed] 
143. Mise, M.; Arii, S.; Higashituji, H.; Furutani, M.; Niwano, M.; Harada, T.; Ishigami, S.; Toda, Y.; Nakayama, H.; Fukumoto, M.; et al. Clinical significance of vascular endothelial growth factor and basic fibroblast growth factor gene expression in liver tumor. Hepatology 1996, 23, 455-464. [CrossRef] [PubMed]

144. Schmitt, M.; Horbach, A.; Kubitz, R.; Frilling, A.; Haussinger, D. Disruption of hepatocellular tight junctions by vascular endothelial growth factor (VEGF): A novel mechanism for tumor invasion. J. Hepatol. 2004, 41, 274-283. [CrossRef]

145. Park, Y.N.; Kim, Y.B.; Yang, K.M.; Park, C. Increased expression of vascular endothelial growth factor and angiogenesis in the early stage of multistep hepatocarcinogenesis. Arch. Pathol. Lab. Med. 2000, 124, 1061-1065. [CrossRef] [PubMed]

146. Bupathi, M.; Kaseb, A.; Janku, F. Angiopoietin 2 as a therapeutic target in hepatocellular carcinoma treatment: Current perspectives. OncoTargets Ther. 2014, 7, 1927-1932. [CrossRef]

147. Torimura, T.; Ueno, T.; Kin, M.; Harada, R.; Taniguchi, E.; Nakamura, T.; Sakata, R.; Hashimoto, O.; Sakamoto, M.; Kumashiro, R.; et al. Overexpression of angiopoietin-1 and angiopoietin-2 in hepatocellular carcinoma. J. Hepatol. 2004, 40, 799-807. [CrossRef] [PubMed]

148. Ker, C.G.; Chen, H.Y.; Juan, C.C.; Lo, H.W.; Shen, Y.Y.; Chen, J.S.; Lee, K.T.; Sheen, P.C. Role of angiogenesis in hepatitis and hepatocellular carcinoma. Hepatogastroenterology 1999, 46, 646-650. [PubMed]

149. Garcia-Monzon, C.; Sanchez-Madrid, F.; Garcia-Buey, L.; Garcia-Arroyo, A.; Garcia-Sanchez, A.; Moreno-Otero, R. Vascular adhesion molecule expression in viral chronic hepatitis: Evidence of neoangiogenesis in portal tracts. Gastroenterology 1995, 108, 231-241. [CrossRef]

150. Nasimuzzaman, M.; Waris, G.; Mikolon, D.; Stupack, D.G.; Siddiqui, A. Hepatitis C virus stabilizes hypoxia-inducible factor 1alpha and stimulates the synthesis of vascular endothelial growth factor. J. Virol. 2007, 81, 10249-10257. [CrossRef] [PubMed]

151. Wilson, G.K.; Brimacombe, C.L.; Rowe, I.A.; Reynolds, G.M.; Fletcher, N.F.; Stamataki, Z.; Bhogal, R.H.; Simoes, M.L.; Ashcroft, M.; Afford, S.C.; et al. A dual role for hypoxia inducible factor-1alpha in the hepatitis C virus lifecycle and hepatoma migration. J. Hepatol. 2012, 56, 803-809. [CrossRef] [PubMed]

152. Medina, J.; Caveda, L.; Sanz-Cameno, P.; Arroyo, A.G.; Martin-Vilchez, S.; Majano, P.L.; Garcia-Buey, L.; Sanchez-Madrid, F.; Moreno-Otero, R. Hepatocyte growth factor activates endothelial proangiogenic mechanisms relevant in chronic hepatitis C-associated neoangiogenesis. J. Hepatol. 2003, 38, 660-667. [CrossRef]

153. Mazzanti, R.; Messerini, L.; Monsacchi, L.; Buzzelli, G.; Zignego, A.L.; Foschi, M.; Monti, M.; Laffi, G.; Morbidelli, L.; Fantappie, O.; et al. Chronic viral hepatitis induced by hepatitis C but not hepatitis B virus infection correlates with increased liver angiogenesis. Hepatology 1997, 25, 229-234. [CrossRef] [PubMed]

154. Mas, V.R.; Maluf, D.G.; Archer, K.J.; Yanek, K.C.; Fisher, R.A. Angiogenesis soluble factors as hepatocellular carcinoma noninvasive markers for monitoring hepatitis $\mathrm{C}$ virus cirrhotic patients awaiting liver transplantation. Transplantation 2007, 84, 1262-1271. [CrossRef] [PubMed] 